\title{
Editorial: The Emergence of Climate Litigation in Africa*
}

What are the particular features of climate litigation in Africa? Or, what more is needed to actualise this potentially powerful form of citizen participation in the African context? If and when African climate litigation accelerates, how can we ensure that the outcomes serve the needs of the people of Africa? Is climate litigation as conceived in Global North contexts even a worthwhile focus for African academics and practitioners, given the nature of African energy transitions and the climate change pressures already being felt on the continent? In August 2020 we convened a workshop which sought to begin a conversation around these questions, which we hope will spark interest in, and support understanding of this field, both in practice and in the academy. ${ }^{1}$ This Special Issue is the first collection of articles from that workshop, and our collective response to some of the questions posed above.

\section{Climate Change Cases of the World - Where is Africa?}

Climate litigation is a topic du jour in academic and policy circles. ${ }^{2}$ New cases have rapidly been assimilated to the body of strategic litigation initiated on the part of individuals, civil society actors, non-governmental organizations and even sub-national governments. These cases seek to hold national or federal governments and corporate actors to account for their climate inaction or lack of climate ambition. ${ }^{3}$

The climate litigation trend positions judges and courts as governance actors in a just transition. It has sparked a flurry of analytical and archiving activity, including legislation and caselaw databases. ${ }^{4}$ The rapidly-developing theory and practice of climate litigation holds out that courts and other quasi-judicial forums provide an independent, non-political public forum to ventilate concerns and allow for claims to be heard and determined. Proponents of the climate litigation trends hold out that legal advocacy can provide a mechanism for dialogue and awareness, draw attention to regulatory options and debates, and push policymakers and regulators to fill gaps in climate change policies, laws and actions. The climate litigation trend opens up a new legal terrain, encouraging courts to hold their

DOI: $10.21552 / \mathrm{cclr} / 2021 / 2 / 3$

* We have been able to publish this collection fully open access due to generous support from a number of sources, which we pooled to pay the full access fee for the edition. We are grateful to the Modern Law Review for allowing us to use residual seminar funding for this. Thanks also to the University of Graz, University of the Witwatersrand, Natural Justice and the University of Exeter for their contributions.

1 This workshop was supported by grant funding from the Modern Law Review Seminars Fund. We are extremely grateful to the MLR for this funding, and their support and flexibility as we moved the Workshop online during the early months of the pandemic.

2 Joana Setzer and Lisa C Vanhala, 'Climate Change Litigation: A Review of Research on Courts and Litigants in Climate Governance' (2019) 10 Wiley Interdisciplinary Reviews: Climate Change e580.

3 Joana Setzer and Catherine Higham, 'Global Trends in Climate Change Litigation:2021 Snapshot' (Grantham Research Institute on Climate Change and the Environment and Centre for Climate Change Economics and Policy, London School of Economics and Political Science 2021) <https://www.Ise.ac.uk/granthaminstitute/wp-content/uploads/2021/07/Global-trends-in-climate-change-litigation_2021 -snapshot.pdf> accessed 10 July 2021, from 23.

4 Sabin Center for Climate Law and Policy 'Climate change litigation databases' <http://climatecasechart.com/climate-change-litigation/> accessed 10 July 2021; Grantham Institute at the London School of Economics 'Climate Laws of the World database' <https://climate-laws .org/> accessed 3 July 2021. 
governments and corporate actors to account to ensure that climate change commitments are given practical and enforceable effect.

But as this global phenomenon gains pace, Africa's marginalization is reproduced. A mere $1.5 \%$ of the cases listed in the Sabin Center's Climate Change Cases of the World database are from Africa (9 out of 450). ${ }^{5}$ The successive legislative surveys that have built the Climate Legislation of the World database have left out 15 African countries, while the coverage of other countries leaves out recent, and critical, information. This could create an impression that there is little legislation or advocacy engaging with climate change in African countries, but this is not the case. ${ }^{6}$ Furthermore, the theoretical conceptualization of climate litigation has been shaped by multi-party actions in the Global North that focus on climate change - and specifically mitigation - directly. Attention has only recently been directed to climate litigation in the Global South. ${ }^{7}$ However despite the scholarly recognition that Global South climate litigation will follow distinct trends, the tone and focus of global advocacy and analysis has not embraced this plurality. The understanding of climate litigation in an African context is even sparser. The global conversation about climate litigation will only become comprehensive when it encompasses the full global range of litigious action in relation to climate change.

\section{What Will Shape Climate Litigation in Africa?}

The particular features of climate litigation in Africa will be informed by the particular relationship Africa has with climate change, as well as the legal (which to some extent must mean economic) resources available to contest these. As a starting point, the nature of African climate litigation will be determined by the particular way that climate change affects the continent, which is determined by geography but also by features of governance, resourcing and economic structures, and historic contribution.

In the aggregate, the particular stressors on the continent include Africa's geographic and social vulnerability to the impacts of climate change, including increased risk of drought, desertification, food instability, increased disease and consequential social unrest and migration; and low (or no) adaptive capacity. ${ }^{8}$ With exceptions, climate governance is closely associated with climate risk, and as such is disaggregated and interwoven into governance systems, including but not limited to natural resources governance. ${ }^{9}$

5 Kenya: Save Lamu et al v. National Environmental Management Authority and Amu Power Co. Ltd (finalised); Nigeria: Gbemre v. Shell Petroleum Development Company of Nigeria Ltd (finalised). South Africa: Earthlife Africa Johannesburg v. Minister of Environmental Affairs (finalised), Philippi Horticultural Area Food \& Farming Campaign v. MEC for Local Government, Environmental Affairs and Development Planning: Western Cape (finalised); Trustees for the Time Being of the Groundwork Trust v. Minister of Environmental Affairs, Kipower (launched); Trustees for the Time Being of Groundwork v. Minister of Environmental Affairs, ACWA Power (launched). Uganda: Mbabazi \& others v. The Attorney-General and National Environmental Management Authority (launched); South Durban Community Environmental Alliance v. Minister of Environment and Others (launched); SDCEA \& Groundwork v. Minister of Forestry, Fisheries, and the Environment (launched)

6 See Olivia Rumble, 'Facilitating African Climate Change Adaptation Through Framework Laws' (2019) 13 Carbon \& Climate Law Review 237.

7 See for instance Jacqueline Peel and Jolene Lin 'Transnational climate litigation: The contribution of the global South' (2019) 113 American Society of International Law 4, 679, shines a light on the contribution of the Global South to transnational climate litigation.

8 Isabelle Niang et al, 'Africa' in V R Barros et al (eds.) Climate Change 2014: Impacts, Adaptation, and Vulnerability. Part B: Regional Aspects. Contribution of Working Group II to the Fifth Assessment Report of the Intergovernmental Panel on Climate Change (Cambridge University Press, 2014) 1199-1265.

9 Rumble (n 6). 
This is where the likely space for climate litigation could emerge, subject to other factors.

Another factor that will significantly shape and influence the governance of climate change are the duties born by African states in relation to climate change, and the need or opportunities - this creates for legal action. Of course, Africa is a huge continent with significant heterogeneity both between and within states - from relatively high-emitting emerging market economies to some least developed countries. Most African states have contributed very little the global climate problem, but do bear responsibilities to peoples within its territories, and beyond, as the effects of climate change become more pronounced. This will include the need to balance ongoing developmental and resource challenges with climate change adaptation, ${ }^{10}$ as well as the pressure to manage increased displacement in response to both high-impact and slow-onset changes. ${ }^{11}$

Questions of historical contribution and the pressure to mitigate also, to some extent, determine the priorities that will be litigated. Because of resource constraints (including poorly resourced courts) and Africa's minimal contribution to climate change, it is more likely that what might be framed or analysed as climate challenges will be embedded in litigation about localised environmental harm or pollution control, natural resource provision or infrastructure projects. ${ }^{12}$ In such cases, the climate policy aspects may be incidental to, or even unmentioned, in the adjudicated dispute, yet where any decision has implications for climate policy, such a decision requires analysis. ${ }^{13}$

It also must be recognised that an inevitable feature of African climate litigation will be its transnational nature, whether involving litigation partnerships, defendants domiciled in the Global North or involving relationships and connections between different African states or regional bodies. ${ }^{14}$ This makes sense, for in as much as climate risk and climate impacts will need to be managed within African states, in the most part climate change is not and has not been caused in African states. Where local industry contributes, the financial benefits of these activities are frequently taken offshore to be enjoyed in other countries - including former colonial powers. ${ }^{15}$ But litigation initiated abroad carries resource and opportunity costs, as much as it may support immediate solutions. ${ }^{16}$

10 World Meteorological Organization, 'State of the Climate in Africa' <https://library.wmo.int/doc_num.php?explnum_id=10421> accessed 12 May 2021, from 25.

11 Persons displaced by disasters and slow onset events continue to move internally and cross borders in a quest for survival. See Ademola Oluborode Jegede, 'Rights Away from Home: Climate-Induced Displacement of Indigenous Peoples and the Extraterritorial Application of the Kampala Convention' (2016) 16 African Human Rights Law Journal 58; Oliver C Ruppel, 'Climate-ChangeInduced Movement of Persons in Africa: Human Rights Responses to Aspects of Human Security', Climate Change: International Law and Global Governance (Nomos Verlagsgesellschaft mbH \& Co KG 2013).

12 Jacqueline Peel and Jolene Lin, 'Transnational Climate Litigation: The Contribution of the Global South' (2019) 113 American Journal of International Law 679; Joana Setzer and Lisa Benjamin, 'Climate Litigation in the Global South: Constraints and Innovations' (2020) 9 Transnational Environmental Law 77; regarding infrastructure see Sanja Bogojević and Mimi Zou, 'Making Infrastructure "Visible" in Environmental Law: The Belt and Road Initiative and Climate Change Friction' (2021) 10 Transnationa Environmental Law 35

13 Kim Bouwer, 'The Unsexy Future of Climate Change Litigation' (2018) 30 Journal of Environmental Law 483; for examples in the South African context, see Melanie Murcott and Emily Webster, 'Litigation and Regulatory Governance in the Age of the Anthropocene: The Case of Fracking in the Karoo' (2020) 11 Transnational Legal Theory 144.

14 Peel and Lin (n 12).

15 Murcott and Webster (n 13).

16 Samvel Varvastian and Felicity Kalunga, 'Transnational Corporate Liability for Environmental Damage and Climate Change: Reassessing Access to Justice after Vedanta v. Lungowe' (2020) 9 Transnational Environmental Law 323. 


\section{The Cases}

The databases of climate cases maintained in London and New York focus predominantly on overt challenges to fossil-fuel industries or projects. ${ }^{17}$ Much of the scholarship that exists either maps the current field (although not beyond the 'database' cases) ${ }_{1}^{18}$ analyses the doctrinal scope and effect of existing litigation, ${ }^{19}$ or examines the possibilities and future directions. It is sensible and worthwhile to touch on these 'recognised' climate cases on a continent that has had inadequate treatment, but this picture is both partial and incomplete.

To discuss the more prominent cases: one of the earliest, Gbemre, ${ }^{20}$ was an action brought on human rights grounds against fossil fuel companies and the Republic of Nigeria. The presiding judge acknowledged that the environmental harm caused by fossil fuel companies, contributed to 'global warming', and constituted a violation of the claimants' rights. Save Lamu, brought in Kenya, also challenged authorisation for a coal mine, and also relied on the legislative framework under which the environmental impact assessment was conducted. The tribunal found that inadequate participatory process had undermined the legality of the consultation, and hence the authorisation. ${ }^{21}$

The rest of the field is dominated by South Africa, where litigation campaigns focus on challenges to mining and power generation dependant on coal. These reflect resistance to long term investments in fossil fuel infrastructure, as well as localised pollution, and the risk to water supplies - a major developmental and climate adaptation challenge in Southern Africa - which is a thread running through the cases. ${ }^{22}$ The South African cases depend heavily on the landmark Thabametsi decision, in which the claimants challenged the defendants' authorisation, which was based on an environmental impact assessment that failed properly to take account of climate change impacts. ${ }^{23}$ This decision has been relied upon in subsequent challenges to coal mining infrastructure, ${ }^{24}$ as well as a challenge to a decision to rezone agricultural land, for reasons including the risk this would pose to a local aquifer. ${ }^{25}$

While the above reflects the range of domestic decisions identified by the databases, it is very clear that more is to come. At the time of writing, in addition to increasing numbers of challenges to new fossil fuel infrastructure in South Africa, there are at least three significant pending cases that deserve attention. In Uganda, Mbabazi is an application brought

17 See <http://blogs2.law.columbia.edu/climate-change-litigation/non-us-jurisdiction/> and <https://climate-laws.org/> accessed 1 August 2021 . This is not a criticism - the methodological challenges involved in tracking 'under the radar' litigation across a vast range of jurisdictions is acknowledged.

18 Louis J Kotzé and Anél du Plessis, 'Putting Africa on the Stand: A Bird's Eye View of Climate Change Litigation on the Continent' (2019) 50 University of Oregon's Journal of Environmental Law and Litigation 30, 615 - 663.

19 Tracy-Lynn Humby, 'The Thabametsi Case: Case No 65662/16 Earthlife Africa Johannesburg v Minister of Environmental Affairs' (2018) 30 Journal of Environmental Law 145; Jean-Claude N Ashukem, 'Setting the Scene for Climate Change Litigation in South Africa: Earthlife Africa Johannesburg v Minister of Environmental Affairs and Others [2017] ZAGPPHC 58 (2017) 65662/16' (2017) 13(1) LEAD 35.

20 Gbemre $v$ Shell Petroleum Development Company of Nigeria Ltd and Others (2005) FHC/B/CS/53/05.

21 Save Lamu et al v National Environmental Management Authority and Amu Power Co Ltd Tribunal Appeal No. Net 196.

22 See Kim Bouwer 'The Influence of Human Rights Arguments on Climate Litigation in Africa' - working paper on file with the author.

23 For a detailed overview, see Humby (n 19).

24 For further discussion of finalized and pending South African cases see Tracy-Lynn Field 'Climate change litigation in South Africa: Firmly out the starting blocks' in Ivano Alogna et al Climate Change Litigation: Global Perspectives (Brill, 2021$) 173$ - 198.

25 Philippi Horticultural Area Food \& Farming Campaign v MEC for Local Government, Environmental Affairs and Development Planning: Western Cape (2020) (16779/17) [2020] (3) SA 486 (WCC). 
by an NGO, Greenwatch, seeking declaratory and mandatory relief on the grounds that the Ugandan government's failure to take both mitigation and adaptation action has violated the claimants' right to a healthy environment, ${ }^{26}$ and also constitutes a breach of public trust. Mbabazi is listed for hearing in July 2021, and could yield a significant African climate change decision. ${ }^{27}$ Proceedings have also been brought to challenge various failings by the Ugandan government which it is alleged violated the claimants' rights when the Baduda landslides in 2019. ${ }^{28}$ This action is currently pending before the High Court in Mbale.

Litigation has also been brought by a coalition of civil society organisations to challenge the recent agreement to construct the East Africa Crude Oil Pipeline. The pipeline is challenged in the East African Court, on the basis that Ugandan law was not complied with when its foundational treaty was agreed. The claimants seek a temporary injunction to stop development. $^{29}$

\section{The Articles}

The articles in this collection make a start on answering the questions posed at the beginning of this short introduction. Most importantly, they highlight the competing priorities underlying, and the very particular and subtle nature of, African climate litigation.

In their article, Eva Maria Anyango Okoth and Mark Odaga provide an overview and analysis of ongoing climate advocacy and litigation campaigns. ${ }^{30}$ Their analysis illuminates the complex and overlapping issues which confront environmental activists in this context, and in particular, the tensions around climate and development. They highlight the value and potential existing legal remedies offer in future and ongoing climate challenges. For instance, they explain the value of environmental impact assessment as an effective tool in environmental challenges, and query the extent to which both regional and domestic human rights protection might feature in future challenges.

This is complemented by the analysis from Samantha Atukunda Mwesigwa and Peter Davis Mutesasira. ${ }^{31}$ In their article, they highlight the tension between the potential use of litigation as a means of protection of environmental rights, the ideals of the rights of nature which underpins their work, and the technical and resource challenges faced by litigators. Their paper explores the very real challenges and difficulties of litigating environmental harms, and in particular, the barriers and risks created by the need for costs security and the risks of adverse costs orders. In doing so, they support understanding of the incentives and disincentives facing climate and environmental advocates in Uganda.

\footnotetext{
26 Protected under Article 39 of the Constitution of the Republic of Uganda

27 For updates see <https://www.ourchildrenstrust.org/uganda > or <https://www.greenwatch.or.ug/greenwatch-uganda-action>.

28 William Tsama v Attorney General and others, cause no 024 of 2020.

9 For updates see $<$ https://naturaljustice.org/news/>.

30 Eva Maria Anyango Okoth and Mark Odhiambo Odaga, 'Leveraging Existing Approaches and Tools to Secure Climate Justice in Africa' (2021) CCLR this issue, 129

31 Samantha Atukunda K Mwesigwa and Peter Davis Mutesasira, 'Climate Litigation as a Tool for Enforcing Rights of Nature and Environmental Rights by NGOs: Security for Costs and Costs Limitations in Uganda' [2021] Carbon \& Climate Law Review (CCLR) this issue, 139.
} 
These questions of institutional preparedness and capacity come to the fore in Jonathan Klaaren's article. ${ }^{32}$ He provides a careful socio-legal analysis of the difficulties faced by displaced persons seeking support, illustrating how the fine tradition of public interest litigation (in the South African context) did not translate into necessary protections due to insufficient enforcement capacity within the system. His work demonstrates clearly the heightened invisibility of climate displaced persons in a system in which the marginalisation of migrants has severe consequences. He paints a worrying picture of the future, in which a significant number of persons will be displaced, and will undoubtedly struggle to find systems and social infrastructure to support them and defend their interests.

A more hopeful picture is presented by Uzuazo Etemire, who analyses recent jurisprudence in Nigeria against the backdrop of a long and varied battle about the egregious conduct of fossil fuel companies over several decades, arguing that these cases are a significant and unrecognised trend in climate litigation on the continent. ${ }^{33}$ Etemire illustrates that a recent Supreme Court decision not only relaxes standing provisions - creating routes to more litigation by NGOs - but also signals a change in judicial attitudes. The question he poses is whether this would lead to an increase in successful litigation against fossil fuel companies in Nigeria.

This is complemented by Lydia Omuko-Jung's article. She explores recent evolutions in Kenyan law - including a pronounced application of a precautionary approach by the courts, a steady relaxation of standing requirements and introduction of statutory environmental remedies for harms - and explains that these create new opportunities for environmental justice and climate cases. ${ }^{34}$

Finally, the article by Kim Bouwer speaks to the suggestion that transnational litigation will be a feature of climate litigation going forward. ${ }^{35}$ Analysing recent decisions from the London courts arising from harm caused by multinational corporations in African countries, she identifies that a streamlining of jurisdictional rules does seem to open the door for future litigation partnerships. While this is not without its benefits, she sounds a note of caution, explaining that environmental and climate justice considerations may not be exactly aligned, and that transnational partnerships may be subject to power imbalances and conflicting priorities.

We hope the readers of the journal find this collection of articles as stimulating, thought provoking and relevant as we did. We hope they provide food for thought in future scholarly work and advocacy, and make a worthwhile contribution to the nascent conversation about climate litigation in Africa.

Kim Bouwer and Tracy-Lynn Field Guest Editors

\footnotetext{
32 Jonathan Klaaren, 'Xenophobia-Induced Disaster Displacement in Gauteng, South Africa: A Climate Change Litigation Perspective' [2021 Carbon and Climate Law this issue, 150.

33 Uzuazo Etemire, 'The Future of Climate Change Litigation in Nigeria: COPW v NNPC in the Spotlight' (2021) CCLR this volume, 158.

34 Lydia Akinyi Omuko-Jung, 'The Evolving Locus Standi and Causation Requirements in Kenya: A Precautionary Turn for Climate Change Litigation?' [2021] Carbon \& Climate Law Review this issue, 172.

35 Kim Bouwer, 'Substantial Justice? Transnational Torts as Climate Litigation' [2021] Carbon and Climate Law Review forthcoming.
} 